\title{
School standards stress scientific literacy
}

Washington. The final version of longawaited national standards for science education in US schools will be published this week by the National Research Council (NRC), the research arm of the National Academy of Sciences (NAS). Teachers and others hope that the standards will eventually help to raise scientific literacy in the entire population of the United States.

A draft of the standards was published a year ago after considerable controversy. That encouraged schools to stop cramming increasing amounts of scientific knowledge into children's heads, and to emphasize the understanding of scientific concepts, especially through laboratory work (see Nature 372, 489; 1994).

After extensive consultation - including the distribution of 40,000 copies of the draft - the final document puts scientific 'knowledge' on an equal footing with scientific 'understanding'. But it argues that such a balance will be achieved only by teaching fewer facts. "The perceived need to include all the topics, vocabulary and information in textbooks is in direct conflict with the central goal of having students learn scientific knowledge with understanding," it says.

The standards include statements of what pupils should know at different stages in their education. For example, it says that, by the age of nine, they "should have a basic understanding of the properties of objects and materials, life cycles of organisms, objects in the sky, and the use of science and technology in solving simple problems".

The standards also set levels of knowledge and ability for teachers - an important issue in a country where many science teachers have had little scientific education themselves. Detailed specifications are offered to local school boards for planning the professional development of their science teachers, as well as assessing the performance of both students and teachers.

\section{Champion of medical research bows out}

Washington. Biomedical research will lose its strongest Republican ally in the Senate next November with the retirement, announced on 1 December, of Senator Mark Hatfield of Oregon. "The whole community is deeply in Hatfield's debt," says Sam Silverstein of Columbia University, past president of the Federation of American Societies for Experimental Biology (FASEB). "He will be very difficult to replace."

David Moore, vice-president of the American Association of Medical Colleges, says Hatfield's loss will be felt not so much in the budget for the National Institutes of Health (NIH), which has support elsewhere, but in the wide range of research issues in which he took an interest.
The standards suggest that students should be assessed on their ability to apply science to the kind of problems they will encounter in the outside world.

Bruce Alberts, president of the academy and thus chair of the NRC, wants all working scientists to help adopt the report and improve science education in schools. The academy will seek to "mobilize all the scientists and engineers in the country and prepare them to be a force for change in their communities", says Alberts. He suggests interested scientists should spend about four hours a week working with local schools.

Noting that the political tide in the United States is flowing strongly against national standards in general, Alberts adds that the academy will put most of its own effort into promoting the standards at the local and regional level. It will do this through "a year of dialogue" among policy-makers, teachers, scientists, students and parents, which the academy will launch with a meeting in Washington on 9 January and follow up with regional meetings around the country.

The NRC's content standards for 5-17year-olds are broadly consistent with those published by the American Association for the Advancement of Science (AAAS) in 1993, according to officials of both groups. But the NRC goes further by proposing standards for science teaching, as well as the assessment of such teaching. Alberts says that these initiatives will take ten years to make their full impact on those graduating

Alberts, who arrived at the academy in the summer of 1993, and Richard Klausner, chair of the committee responsible for the project since November 1993 and now the director of the National Cancer Institute, are credited with restoring the project's credibility. It had been underway since 1991, but its initial proposals drew criticism for their alleged reliance on the views of non-

A five-term senator, Hatfield has been a tireless champion of both the NIH and US medical schools, and took over the chair of the Senate appropriations committee a year ago.

One of Hatfield's legacies will be a sevenyear budget bill which includes a reasonable allocation for NIH. In a remarkable testament to Hatfield's influence, 85 of the 100 senators voted in June for his amendment to restore \$7 billion to NIH (see Nature 375, 347; 1995). Senator Nancy Kassebaum (Republican, Kansas), the moderate chair of the Senate Labor and Human Resources committee, which oversees NIH, also announced her retirement from the senate two weeks ago.

C. M. from American high schools.

\section{IMAGE UNAVAILABLE FOR COPYRIGHT REASONS}

Science lesson: children should learn fewer facts, but understand more, says the NRC.

scientists who view science as a "social construct" (see Nature 375, 439; 1995).

"No-one at the academy was happy with those early drafts," says Alberts. According to James Trefil, a physicist at George Mason University in Fairfax, Virginia, who sat on a panel which Alberts and Klausner set up to fix the drafts, the project "had fallen into the clutches of post-modernist philosophers". These, he says, saw science as nothing more than "a never-ending change of opinion".

The impact of the standards project will be an important test for Alberts, a prominent molecular biologist who has put education matters squarely at the top of the academy's agenda. Some critics have suggested that, rather than pursuing education issues, he should have been mustering the academy's considerable influence to defend science from threatened budget cuts.

But Alberts is unapologetic. "The good thing about having been a scientist is that I've been working for my whole life on things people say are crazy," he says. "All our [academy] members want us to lobby for every damn thing, but we don't lobby. We're advisors, and you can't be a lobbyist and give independent advice at the same time."

Shorn of the relativist views of post-modernists, and free from the political controversy that has, for example, dogged history teaching standards, the science standards should be able to play a substantial role in revamping science education in US schools, their authors say.

"The scientific community is in agreement on this," says James Rutherford, chief education officer at the AAAS, and a member of a committee that advised Klausner. Trefil adds: "the good news is that there is a consensus amongst the scientists" on what ought to be; the humanities, he points out, are less fortunate.

Colin Macilwain 